\title{
Overrepresentation and Underrepresentation of African Americans and Latinos as Lawbreakers on Television News
}

\author{
by Travis L. Dixon and Daniel Linz
}

\begin{abstract}
We conducted a content analysis of a random sample of local television news programming in Los Angeles and Orange counties to assess representations of Blacks, Latinos, and Whites as lawbreakers and law defenders. "Intergroup" comparisons of perpetrators (Black and Latino vs. White) revealed that Blacks and Latinos are significantly more likely than Whites to be portrayed as lawbreakers on television news. "Interrole" comparisons (lawbreakers $v$ s. law defenders) revealed that Blacks and Latinos are more likely to be portrayed as lawbreakers than as defenders, whereas Whites are significantly more likely to be portrayed as defenders than as lawbreakers. "Interreality" comparisons of lawbreakers (television news vs. crime reports from the California Department of Justice) revealed that Blacks are overrepresented as lawbreakers, and Latinos and Whites are underrepresented as lawbreakers on television news compared to their respective crime rates obtained from the California Department of Justice for Los Angeles and Orange counties. Interreality comparisons of law defenders (television news $v$ s. county employment records) revealed that Whites are overrepresented, Latinos are underrepresented, and Blacks are neither over-nor underrepresented as police officers on television news compared to employment reports. We speculate on the psychological effects of exposure to these intergroup, interrole, and interreality differentials on television news viewers.
\end{abstract}

Crime stories in the news may shape public conceptions of order and justice in society (Gans, 1979; Hall, Critcher, Jefferson, Clarke, \& Roberts, 1978). Hall et al. (1978) theorized that crime news reaffirms the "consensual morality" of society.

\footnotetext{
Travis L. Dixon is assistant professor of communication studies and a faculty associate at the Institute for Social Research at the University of Michigan. He is primarily interested in the portrayal of African Americans in the mass media and the effects of these images on audiences. Daniel Linz is professor of communication, law, and society and chair of the law and society program at the University of California, Santa Barbara. His major research interests are in social science and the law, psychology and the law, and communication law, particularly with regard to issues of sex and violence. An earlier version of this work was presented at the International Communication Association in Jerusalem, Israel, July 1998. The authors would like to thank the numerous research assistants who helped collect data for this project. Correspondence concerning this article should be addressed to Travis L. Dixon, University of Michigan, Department of Communication Studies, 3020C Frieze Building, Ann Arbor, MI 48109-1285 USA; email: tldixon@umich.edu.
} 
The portrayal of crime on television news represents "a modern play" in which the "devil" is both symbolically and physically cast out from the society by its "guardians-the police and the judiciary" (Hall et al., 1978, p. 66). Perpetrators of crime portrayed in the news represent the "evil forces" that need to be controlled in order to maintain social order (Barlow, Barlow, \& Chiricos, 1995; Miller, 1998). If the perpetrators of crime on television news are largely people of color and guardians of law usually White, then viewers of news programs may come to the conclusion that people of color are evildoers who must be subdued.

The present study is a content analysis designed to ascertain whether television news programs present crime in such a way as to perpetuate "misrepresentations" or "distortions" of African American and Latino citizens' propensity toward criminality in society. Conversely, this study attempts to measure whether television news has a tendency to distort the contributions of Whites as guardians of order in society by representing them as police officers or other defenders of law.

The notion that African Americans and Latinos may be represented as lawbreakers while Whites are portrayed as law defenders on television news is partially informed by an "ethnic blame discourse" (Romer, Jamieson, \& DeCoteau, 1998; van Dijk, 1993). According to this theoretical perspective, ethnocentric talk becomes routinized in everyday speaking and shapes the thoughts and actions of persons exposed to the discourse. The ethnic blame discourse frames problem behavior committed by ethnic Others (e.g., Blacks and Latinos) as intergroup conflict and accentuates the harmful effects of the behavior for the in-group (e.g., Whites). As a result, Black and Latino perpetration of crime, particularly if Whites are victims, may occur frequently on news programs. Whites, however, should occupy benign or helpful roles on television news programming.

As a result of such an ethnic blame discourse, a cognitive association of Blacks and Latinos with lawbreaking and Whites with law defending might develop. The cultivation hypothesis and theories of stereotyping derived from the social cognition perspective suggest that just such an association may be likely. The cultivation hypothesis suggests that heavy viewers of television come to believe that the real world is much like the television world (Gerbner, 1969, 1990). Stereotype theories of social cognition suggest that stereotypes (i.e., cognitive structures) may be formed by consistently seeing out-group members in stereotypical roles on television over a long period of time (Hamilton, Stroessner, \& Driscoll, 1994). If Blacks and Latinos on television news are portrayed as criminals, then White viewers' mental categories involving Blacks and Latinos might develop from these depictions. Taken together, the cultivation hypothesis, an ethnic blame discourse, and social cognitive theories of stereotyping predict that White viewers would come to cognitively link lawbreaking behaviors with African Americans and Latinos as a group if they were overrepresented as criminals on television news.

\section{Investigating the Portrayals of Race, Lawbreaking, and Law Defending}

The first step in understanding whether such an overrepresentation with lawbreaking might have an effect on viewers involves understanding whether the 
portrayals of Black and Latino lawbreaking on television news differ from social reality. This study is designed to investigate this issue. Three indexes of Black, Latino, and White lawbreaking and defending are applied to television news representations: (a) "intergroup" comparisons of lawbreakers by race and cultural group; (b) "interrole" comparisons of lawbreakers vs. law defenders within cultural and racial group; and (c) "interreality" comparisons of law breakers presented on television news with crime reports obtained from the California Department of Justice, and comparisons of law defenders presented on television news with county employment records by racial and cultural group.

Researchers have used one or another of these comparisons in content analyses to investigate how African Americans, Latinos, and Whites are represented on television news and other "reality based" programming (Entman, 1992, 1994; Oliver, 1994; Romer, Jamieson, \& DeCoteau, 1998; Sorenson, Manz, \& Berk, 1998; Turk, Richstad, Bryson, \& Johnson, 1989). This study, we believe, is the first to use all three in order to investigate lawbreaking and law defending. Each comparison index provides different information about the portrayal of these groups on television news, and each carries underlying assumptions about the effects of exposure to news on viewers. A brief review of how past research has employed each of these comparisons and the interpretations lent to each measure is offered below.

\section{Intergroup Comparisons of Lawbreakers}

The intergroup content measurement approach employed in previous research has generally involved comparing portrayals of Black or Latino perpetrators of crime to White perpetrators portrayed on television news. An illustration of the intergroup comparison approach is provided by Entman (1992), who performed a content analysis of 55 days of local television news in Chicago. He undertook an intergroup comparison of Whites to Blacks in order to investigate differences in certain features of the portrayals of Blacks and Whites in crime stories. He found that Blacks (38\%) accused of a crime were much more likely than similarly accused Whites (18\%) to be shown in the grip of a restraining police officer. He also found that Black perpetrators (49\%) were less likely to be named than White perpetrators (65\%). Entman interpreted such differences as evidence that when African Americans and Whites are accused of similarly serious offenses, Blacks appear to be treated in a more "dehumanized" manner than Whites. Moreover, Entman maintained that those Blacks most dehumanized appear to be perpetrators of violence against Whites.

We could locate no empirical content analysis of depictions of Latinos on television news. However, Turk et al. (1989) has undertaken a content analysis of newspapers in Albuquerque and San Antonio. Utilizing an intergroup comparison approach, they found that Latinos (26\%) were more likely than Whites (17\%) to be central characters in stories involving "problem" issues (e.g., judicial and crime news, news of riots and demonstrations, and accident and disaster news).

\section{Interrole Comparisons of Lawbreakers and Defenders}

Interrole comparisons have involved comparing the number of portrayals of perpetrators of crime within a racial or cultural group to the number of defenders of 
law (i.e., police officers) within the same group. An interrole comparison approach was used by Romer and his colleagues (1998) to investigate the extent to which television news stories emphasize the harm that people of color cause Whites. The researchers conducted a content analysis of the 11:00 p.m. news broadcast for three stations in Philadelphia over 14 weeks. Romer and his associates coded the ethnicity of primary actors (i.e., "person of color" vs. White) in each of the stories and their roles (i.e., victim or perpetrator). They found that Blacks were more likely to be shown as perpetrators (72\%) than as victims (47\%) in the news.

We could locate no studies of interrole comparisons that directly assess whether people of color or Whites are more likely to appear as law defenders (e.g., police officers) vs. perpetrators of crime on television news. However, such interrole comparisons could easily be made. It is also important to note that a few studies have suggested that Blacks are often overrepresented as police officers on entertainment programming (Clark, 1973; Deroche \& Deroche, 1991). Regardless, it is important to consider whether African Americans and Latinos are more likely to be portrayed as officers than as perpetrators on television news because the news may be seen as a more realistic reflection of reality than entertainment programs (Perse, 1990).

\section{The Utility of Intergroup and Interrole Comparisons}

Intergroup and interrole comparisons in content analysis are useful for at least two reasons. First, they offer us a convenient and easily calculated measure of the content of the television news environment with regard to race and crime. These summary measures can then be used to compare various forms of mass media content or document trends in television content over time. Second, intergroup and interrole comparisons are important because they represent specific mixtures of television content that may lead to particular psychological effects in viewers.

As with the risk ratios employed by Gerbner and his colleagues in content analyses of the larger television environment, intergroup and interrole comparisons of perpetrators by race on local television news may be interpreted as indicators of the social reality potentially cultivated among news viewers (Gerbner, 1990; Gerbner, Gross, Morgan, \& Signorielli, 1980). The presumption here is that viewers embrace the version of the social world cultivated by television news and incorporate it into their view of social reality. The presentation of Blacks in the role of perpetrators of crime relative to other roles such as crime victims or law defenders on television news may lead viewers to believe that their social world is populated by African Americans who are dangerous and prone to crime (Armstrong \& Neundorf, 1992; Gilliam, Iyengar, Simon, \& Wright, 1996; Johnson, Adams, Hall, \& Ashburn, 1997).

In social-psychological terms, if television news portrays significantly more Blacks and Latinos as perpetrators of crime than Whites, negative stereotypes of Blacks and Latinos as criminals may be perpetuated in the minds of viewers. Conversely, if the interrole comparison reveals that Blacks and Latinos are more likely to be portrayed as law defenders rather than as perpetrators, this might be a form of counterstereotypical information that discourages a cognitive association between Blacks and lawbreaking (Bogatz \& Ball, 1972; Gorn, Goldberg, \& 
Kanungo, 1976). In sum, intergroup and interrole comparisons may be useful because they identify content that may increase or decrease the cognitive linkage between people of color and criminal behavior.

\section{Interreality Comparisons of Lawbreakers and Defenders}

Interrole and intergroup comparisons allow us to measure the television environment and imagine effects in viewers' cognitive representations of the social world after exposure to television. However, these comparisons tell us little about the "accuracy" of the media portrayals or the stereotypes and beliefs that are subsequently cultivated in viewers. It may be the case that Blacks are, in fact, more likely than Whites to commit crime depending on what index of crime is used as a comparison point. In this sense, television news may disseminate an accurate picture of the world rather than cultivate a distorted view. Intergroup and interrole measures must therefore be anchored to objective indicators of social reality that are measured outside the television environment, both in order to evaluate claims of the accuracy of media representations and in order to provide a basis for speculating on and evaluating the potential effects of news on viewers.

To make the claim that media portrayals overrepresent, underrepresent, or accurately represent Blacks and Latinos as either perpetrators or as law defenders, intergroup and interrole comparisons must be augmented by other measures. Oliver (1994) investigated the extent to which Blacks were represented as criminals in police and crime reality programs shown in the 1991-1992 fall television schedule. ${ }^{1}$ She employed an interreality approach by comparing television portrayals of criminal suspects to crime data collected by government law enforcement agencies. Oliver found that Blacks comprised 36\% of the perpetrators on reality programs. She compared this finding to the percentage of Black criminal suspect arrests listed in the FBI's Uniform Crime Reports. Here, Blacks comprised only 30\% of criminal suspects. Further, Blacks accounted for $9 \%$ of police officers presented in reality-based programs, whereas the remaining 91\% of the police officers were White. However, Blacks comprise 17\% of police officers whereas Whites account for the remaining $83 \%$ of police officers, according to employment data.

Another example of a study that utilized an interreality comparison was performed by Sorenson et al. (1998). They compared 2,782 stories featured in the LoS Angeles Times about homicide, with the 9,442 homicides that occurred in LA County from 1990-1994, according to official government reports. They found that Latinos were underrepresented as homicide suspects, and that Black and Latino victims were underrepresented as well.

\section{The Utility of Interreality Measures}

Interreality comparisons of perpetrators and law defenders on television with social indicators measured outside of the media, such as government reports,

\footnotetext{
${ }^{1}$ These programs typically employ dramatizations of actual crimes interspersed with narration from and interviews with police officers and included Cops, Top Cops, America's Most Wanted, FBI, The Untold Story, and American Detective.
} 
focus our attention on certain psychological effects on viewers. For example, the overrepresentation of Blacks as lawbreakers and underrepresentation of Blacks as law defenders on television may have the effect of distorting viewers' perceptions of Blacks as dangerous in our society. Overrepresentation of Blacks as perpetrators of crime and underrepresentation as law defenders on television news compared to official reports may facilitate fears of victimization by Black and Latino perpetrators among news viewers. These viewer fears would be "unrealistic" to the degree that they strayed significantly from the "social reality" of crime reports (Gilliam et al., 1996; Romer et al., 1998).

To date there are few content analyses of television news that utilize an interreality comparison that focuses on perpetrators. Dominick (1978), Graber (1980), and Jerin \& Fields (1994) have all utilized or reported on interreality comparisons that focused on whether the crimes portrayed in the media (mostly newspapers) were consistent with the commission of crime as indicated by government reports. A new study that addresses the portrayal of perpetrators and race on television news is important for two primary reasons. First, television news is used as a primary source of information by U.S. citizens (Klite, Bardwell, \& Salzman, 1997). Second, television news may have a demonstrable effect on public opinion that is yet to be found for crime programs. Several studies have provided evidence that the news media are especially influential in shaping public opinion on important law and policy issues (Gilliam et al., 1996; Iyengar \& Kinder, 1987; Klite et al., 1997).

\section{Three Indexes of Race and Crime Representations on TV News}

Each of the three indexes described above (i.e., intergroup comparisons, interrole comparisons, and lawbreaker and law defender interreality comparisons) is used in the present study to analyze the extent to which Blacks and Latinos are overrepresented, underrepresented, or accurately represented as perpetrators of crime and defenders of law on television news. Employing all of these measures in one study provides a more comprehensive view of the portrayal of these groups on television news. Further, as we discussed above, each measure may suggest a unique psychological effect on television viewers. It is important then to determine the extent to which each differential is present in television news.

\section{Hypotheses}

Based upon prior research that suggests that African Americans and Latinos are likely to appear more often as lawbreakers than as law defenders, this research employs interreality, intergroup, and interrole comparisons to test three hypotheses:

H1: Blacks and Latinos will appear as perpetrators at a higher rate compared to Whites.

This hypothesis is tested by intergroup comparisons that measure the degree to which Blacks and Latinos are portrayed as perpetrators compared to Whites. 
H2: Blacks and Latinos will appear as lawbreakers at a higher rate compared to law defenders; however, Whites will appear as law defenders at a higher rate compared to lawbreakers.

This hypothesis is tested by interrole comparisons of the degree to which Blacks, Latinos, and Whites are more or less likely to be portrayed as perpetrators of crime than as defenders of the law.

H3a: The distribution of perpetrators of crime by race on television news will be inconsistent with the distribution of arrests in crime reports by race.

This hypothesis is tested by an interreality comparison that involves a direct assessment of the overrepresentation or underrepresentation of Blacks, Latinos, and Whites as lawbreakers on television news. In the present study, the social reality indicator used for perpetration is the Criminal Justice Profile for 1995 and 1996, published by the California Department of Justice (1996, 1997). If the proportion of perpetrators on television news is greater than the proportion noted in crime reports, this is a clear indication of overrepresentation.

H3b: The distribution of law defender roles on television news will be incon-

sistent with those in employment records.

This question is answered by an interreality comparison that involves a direct assessment of the overrepresentation or underrepresentation of Blacks, Latinos, and Whites as law defenders. The social reality indicators used for law defending are the employment records provided by Los Angeles and Orange counties (County of Orange, 1996; Los Angeles County Sheriff's Department, 1996; Los Angeles Police Department, 1997). A lower proportion of Black, Latino, and White defenders of law on television news than that noted in employment records indicates underrepresentation.

\section{Method}

\section{Sample of Programs}

News programs were drawn from broadcasts aired by Los Angeles-based stations to represent the population of interest, all local news programs aired in Los Angeles and Orange counties. These two counties represent the primary metropolitan areas for Los Angeles-based stations (Nielsen Media Research, 1994). The sample in this study was drawn using procedures developed by researchers involved in the National Television Violence Study (NTVS; Kunkel et al., 1996; Potter et al., 1998; Wilson et al., 1998).

\section{Obtaining a Representative Sample of the Program Population}

The programs in the present study were selected with a modified version of the equal probability of selection method (EPSEM). With this method of selection, every program has an equal chance, or opportunity, to appear in the sample. This method increases the chances that the sample represents the characteristics of the population of television news programs under study. 
Two half-hour time slots (defined by hour of day and day of week) were randomly selected for each channel during each week that the sampling occurred. Once a time slot was selected, TV Guide was consulted and the program corresponding to that time was entered into a scheduling grid several days before the target week of programming began. Programs were retained in their entirety regardless of the number of time slots they occupied. For example, if the time slot 4:30 was randomly selected and an hour-long news program that began at 4:00 p.m. was identified in the $T V$ Guide, the 4:00 p.m. program was selected for inclusion in the sample and permitted to occupy two half-hour time slots (4 p.m.5 p.m.).

\section{Basic Parameters of the Sample}

The sampling frame for the present investigation was defined by four parameters: channels, program types, sampling times (i.e., times of day), and sampling periods (i.e., times of year). The following channels were included in the sample: KABC (ABC affiliate), KCBS (CBS affiliate), KNBC (NBC affiliate), KCAL, KCOP, FOX, and KTLA. Only breaking news programs (e.g., programs that self-identify as "news") were coded, and all breaking news programs listed in TV Guide from 3:00 p.m. until 10:59 p.m. were eligible for inclusion in the sample (a total of 7 hours per day). The sampling period was a set of 20 weeks beginning October 7 , 1995, and ending June 7, 1996; however, the time periods during certain holidays (e.g., Thanksgiving, Christmas, and Easter) were excluded from the sampling frame.

Using the sampling procedure described above, a 7-day composite week of news programming was produced. Virtually all news shows in the regular program schedule for each channel appeared in the final composite week. The taped news sample included 118 programs. A total of 2 (1.9\%) were removed from the sample because of taping errors or other technical problems, yielding 116 programs.

\section{Definitions of Crime and Race}

Definition of crime. Crime was defined as behavior or information either pertaining to the commission of a particular lawbreaking act, or social or legal reaction to lawbreaking more generally. Only those crimes (e.g., murder, arson, robbery) that are tracked by the U.S. Department of Justice and the State of California Justice Department were coded to compare the depiction of crime on the news with crime data. $^{2}$

Definition of perpetrator race. To compare the race of individuals portrayed on television news with the race of individuals noted in crime reports, the categories

\footnotetext{
2 Arrest rates themselves may be a function of racial discrimination. Jones (1986) reports that Blacks are arrested twice as often as Whites, and Blacks are jailed at a rate over four times their proportion in the population. Despite this potential bias, these reports are used for three reasons. First, the only government information that was available to us regarding the race of perpetrators was arrest rate. Second, there is no evidence to suggest that viewers make meaningful distinctions between perpetrators who are accused and sought for a crime versus those who have been arrested for lawbreaking. Third, public officials and other agencies use these reports to develop policy responses to criminal activity.
} 
and definitions used by the California Department of Justice were employed in this study. Race included four categories: Blacks, Whites, Latinos, and others (e.g., Asians).

Identification of race. The following apparent race indicators were used to assess the race of perpetrators: (a) shown on videotape, (b) mug shot shown, (c) artist's sketch shown, (d) photo shown, and (e) race stated. When these more apparent indicators of race were not available, race was inferred based on characteristics of the story. Three variables were used: (a) surname (e.g., Martinez is associated with Latino), (b) family member of perpetrator is shown (e.g., White mother implies White perpetrator), and (c) prior news reports indicate race (e.g., Selena's killer identified in prior news reports as Latina).

Coding multiple perpetrators, judges, police officers, and prosecutors. In a few cases the race of multiple perpetrators or law defenders (e.g., police officers, judges, lawyers) had to be coded. First, coders used a majority rule when coding the race of multiple perpetrators or law defenders on television news. In other words, the category for race was coded based on the attributes of the majority of characters in any one story. Second, when no clear majority arose, coders recorded the primary racial groups present and estimated the number of each group present. In cases where no clear number was given but coders could detect that multiple characters were involved, a conservative number of characters were counted. Third, these frequencies were summed into a final tally for each racial group, and each race was tracked in the analysis.

\section{Levels of Analysis}

The judgments and observations recorded for each instance of lawbreaking were organized into two levels or units of analysis: (a) crime story level, and (b) perpetrator of crime level.

Crime story level. News programs are generally composed of several segments or news stories. We analyzed only news stories that reported criminal behavior. These crime stories represented the first level of analysis in the design. At the crime story level, the following variables were coded: (a) the race (e.g., Black, White, Latino, or other) of police officers, (b) the race of prosecutors, (c) the race of judges, and (d) the location of crimes (committed in Los Angeles or Orange counties or not).

Perpetrator level. Included within many, but not all, of the crime stories were perpetrators of crime. The racial distributions of television news perpetrators were analyzed and compared to crime reports. Coders coded variables pertaining to the crime committed and race of perpetrators. We coded information about perpetrators if any criminal behavior was associated with a character in any crime story. At the perpetrator level, the following variables were coded: (a) the race (e.g., Black, White, Latino, or other) of perpetrators, and (b) the crime committed (e.g., murder, arson).

\section{Coding and Reliability}

We selected 10 undergraduate students with strong academic records to perform the coding of data for this project. Coders underwent approximately 30 hours of 
instruction in a small seminar setting. Coders received five identical programs that they were required to code along with their regular coding assignment. The coding of these five programs provided the reliability data for this study.

\section{Measuring Reliability}

We assigned coders random samples of programs. They then determined which program segments consisted of news stories. Coders identified crime stories, law defenders, and perpetrators of crime within these news stories. Coder consistency in identifying each crime story, perpetrator, and law defender was quite good, given the complexity of the task and the number of coders involved. Across all of the programs examined for reliability, most coders were able to agree on the number of crime stories, perpetrators, and law defenders contained within the news programs.

The proportional reduction of error technique used in this study to assess coder consistency relied on the index $I_{r}$ (Imrich, Mullin, \& Linz, 1995; Perreault \& Leigh, 1989). This index compares the observed frequency of agreement between judges to an expected frequency of agreement given some "true" level of reliability for the coding process. Conceptually, this true level of reliability is "the percentage of total responses (observations) that a typical judge could code consistently given the nature of the observations, the coding scheme, the category definitions, the directions, and the judge's ability" (Perreault \& Leigh, 1989, p. 140). Thus, $I_{r}$ is an estimate, within sampling variance of the true proportion of reliably coded observations.

Perreault and Leigh's (1989) $I_{r}$ was used as the index of reliability to allow for the likelihood that some coding categories may be infrequently used, but may nevertheless be reliably coded (e.g., if the race of most defendants was truly infrequently reported on TV news as Black, coders would much more often be coding this variable as 0 [White] than as 1 [Black], and be accurate in doing so). Because other indexes of reliability, such as Cohen's kappa (Cohen, 1960) or Krippendorff's alpha (Krippendorff, 1980), do not allow for this situation in their estimates of chance agreement (they assume that all categories are equally likely to be used by each judge), such indexes are inappropriate for this data set. Perreault \& Leigh's (1989) $I_{r}$ was computed for each variable using the formula $I_{r}=\left\{\left[F_{0} / N\right)\right.$ $(1 / k)][k /(k-1)]\}^{1 / 2}$ for $F_{0} / N>1 / k$ (where $F_{0}=$ observed frequency of agreement between judges, $N=$ total number of judgments, $k=$ number of categories).

An inferential procedure was also used in order to determine the probability that each of the reliability coefficients could have occurred by chance alone. For each decision, a $z$-score was computed using the following formula developed by Potter et al. (1998):

$$
Z=[X-\mu] / \sigma, \mu=p n, \sigma=\{p q n\}^{1 / 2}
$$

Where $\quad p=$ probability of a single coder selecting the modal value

$q=$ the probability of a single coder not selecting $p$

$n=$ number of coders in test

$X=$ upper real limit of coders at mode 


\begin{tabular}{|c|c|c|c|c|c|c|c|}
\hline \multirow[t]{2}{*}{ Measures } & $\begin{array}{l}\text { KCBS } \\
11 / 08\end{array}$ & $\begin{array}{l}\text { KNBC } \\
10 / 24\end{array}$ & $\begin{array}{l}\text { KCOP } \\
05 / 06\end{array}$ & $\begin{array}{l}\mathrm{KCAL} \\
02 / 02\end{array}$ & $\begin{array}{l}\text { KABC } \\
04 / 25\end{array}$ & Range & $\begin{array}{l}\text { Overall } \\
\text { median }\end{array}$ \\
\hline & \multicolumn{6}{|c|}{ News story level variables } & \\
\hline Police race & .90 & .92 & .92 & .92 & 1.00 & $.90-1.00$ & .90 \\
\hline Prosecutor race & 1.00 & .98 & 1.00 & .97 & 1.00 & $.97-1.00$ & 1.00 \\
\hline Judge race & 1.00 & .94 & .99 & 1.00 & 1.00 & $.94-1.00$ & 1.00 \\
\hline \multirow[t]{2}{*}{ Location of crime } & .88 & .88 & .89 & .84 & .87 & $.84-.89$ & .88 \\
\hline & \multicolumn{6}{|c|}{ Defendant level variables } & \\
\hline Crime committed & .66 & .93 & .88 & .84 & .82 & $.66-.93$ & .84 \\
\hline Race of def & .92 & .95 & .96 & .99 & .94 & $.92-.99$ & .96 \\
\hline \multicolumn{8}{|c|}{ Apparent race indicators } \\
\hline Video of def & $.83+$ & .99 & .95 & 1.00 & .94 & $.83-1.0$ & .95 \\
\hline Mug shot of def & 1.00 & .97 & .99 & 1.00 & 1.00 & $.97-1.0$ & 1.00 \\
\hline Artist sketch of def & 1.00 & .96 & 1.00 & 1.00 & 1.00 & $.96-1.0$ & 1.00 \\
\hline Photo of def & 1.00 & .93 & .94 & 1.00 & 1.00 & $.93-1.0$ & 1.00 \\
\hline Race stated & 1.00 & .93 & .98 & .98 & 1.00 & $.93-1.0$ & .98 \\
\hline \multicolumn{8}{|c|}{ Inferred race indicators } \\
\hline Infer from surname & 1.00 & .98 & .97 & 1.00 & 1.00 & $.97-1.0$ & 1.00 \\
\hline Infer from family & 1.00 & .98 & 1.00 & 1.00 & 1.00 & $.98-1.0$ & 1.00 \\
\hline Infer from $p /$ news & 1.00 & .95 & .98 & 1.00 & 1.00 & $.95-1.0$ & 1.00 \\
\hline
\end{tabular}

$+=p>.05 ;$ coefficients without $+=p<.05$.

Then the $z$-score was looked up in a Unit Normal Table. This indicates the probability of obtaining the observed level of agreement by chance alone. For example, if we ran a test with 12 coders who had to choose among four options and 7 of those coders all chose the same option, the chance of getting 58.3\% agreement ( 7 out of 12 agreeing on the same option out of four) would be less than one in a thousand or $p<.0017$. With only two options available, an agreement of 10 out of $12(83.3 \%)$ would be needed in order to have this same high level of confidence $(p<.001)$ that this pattern could not have occurred by chance alone.

As displayed in Table 1, the reliability on each of the variables was quite high, as indicated by the overall median level of agreement that ranged from .88 to 1.0. We computed a confidence interval for each of the 70 reliability coefficients (14 variables on each of the five programs in the reliability test). Out of those 70 coefficients, only 1 of them-video of perpetrator of crime-was too small to attain statistical significance $(p<.05)$. Given that all the other coefficients for this variable did reach statistical significance over several trials, it was not eliminated from the analysis. Overall, the reliability assessments appear to establish strong confidence in the accuracy of the data reported in the study. 
Table 2. Intergroup Comparisons of Black to White and Latino to White Perpetrators of Crime Portrayed on Television News

$\begin{array}{ll}\text { Black/White } & \text { Latino/White } \\ \text { perpetratora } & \text { perpetrator }^{b}\end{array}$

All perpetrators $\quad 1.72(69 / 40) \quad 1.37(55 / 40)$

Felony perpetrators $\quad 2.46(64 / 26) \quad 1.92(50 / 26)$

a, b Numbers outside the parentheses are ratios. Inside the parentheses are the raw figures used to calculate the ratios. A ratio greater than 1.00 indicates that Blacks and Latinos are more likely to be perpetrators of crime than Whites. For instance, a 2.00 under the Black/ White perpetrator column indicates that for every White perpetrator there are 2.00 Black perpetrators portrayed on television news.

\section{Results}

To allow for comparisons with government crime reports, only those television news crimes committed in Los Angeles and Orange counties were included in the following analyses. In addition, only those stories that featured crimes that are monitored by the California Department of Justice were analyzed. Finally, O. J. Simpson stories were systematically removed from all of the analyses in order to generalize about typical portrayals of Blacks on these programs.

Intergroup Comparisons of Black to White and Latino to White Perpetrators of Crime

Our first hypothesis predicted that Blacks and Latinos will appear as perpetrators at a higher rate than Whites. This hypothesis was supported. As shown in Table 2, Blacks were more likely than Whites to be portrayed as perpetrators on television news. When only felons (e.g., murderers) were included in the analysis, Blacks were almost two and a half times more likely to be portrayed as felons than Whites.

Table 2 also displays the intergroup comparisons for Latino to White perpetrators of crime. They reveal that Latinos were more likely than Whites to be portrayed as perpetrators. When only felons were included in the analysis, Latinos were almost twice as likely as Whites to be portrayed as felony perpetrators.

Interrole Comparisons of Black, Latino, and White Perpetrators to Black, Latino, and White Defenders of Law on Television News

Our second hypothesis predicted that Blacks and Latinos will appear as lawbreakers at a higher rate than as law defenders; however, Whites will appear as law defenders at a higher rate compared to lawbreakers. This hypothesis was also supported. Only a small number of prosecutors and judges are depicted on television news. All (100\%) of the judges were White, and $80 \%$ of the prosecutors were 


\section{Table 3. Interrole Comparisons of Black, White, and Latino Perpetrators of Crime to Police Officers on Television News}

\author{
Black perpetrator/ \\ Black officer ${ }^{a}$
}

All perpetrators

Felony perpetrators

\author{
$3.83(69 / 18)$ \\ $3.56(64 / 18)$
}

White perpetrator/

White officer ${ }^{b}$

$.43(40 / 93)$

$.28(26 / 93)$
Latino perpetrator/

Latino officer $^{c}$

$4.23(55 / 13)$

$3.85(50 / 13)$

$a, b, c$ Numbers outside the parentheses are ratios. Inside the parentheses are the raw figures used to calculate the ratios. A ratio greater than 1.00 indicates that Blacks, Whites, or Latinos are more likely to be perpetrators than officers. For instance, a 4.00 under the Black perpetrator/Black officer column indicates that for every Black officer, there are 4.00 Black perpetrators portrayed on television news.

White. Because judges and prosecutors were so rare, the rest of this report operationalized defenders of law strictly as police officers.

As shown in Table 3, Blacks were almost four times more likely to be portrayed as perpetrators than as police officers. In the case of felonies, Blacks were three and a half times more likely to be portrayed as perpetrators than as police officers. Table 3 also displays the ratios of Latino perpetrators of crime to police officers. They reveal that Latinos were four times more likely to be portrayed as perpetrators than as officers when all perpetrators were included in the analysis. When only felony perpetrators were included, Latinos were again almost four times more likely to be portrayed as perpetrators than as officers. Whites, on the other hand, were less likely to be portrayed as perpetrators than as officers, even when we included only felonies in the analysis.

Interreality Comparison of Perpetrators of Crime on Television News to California Department of Justice Criminal Justice Profile

The first part of our third hypothesis predicted that the distribution of perpetrators of crime by race on television news would be inconsistent with the distribution of arrests in crime reports by race. This hypothesis was supported. Undertaking this analysis involved three steps. In the first step, we calculated the percentages of Blacks, Whites, Latinos, and others among Los Angeles County and Orange County perpetrators (sought, arrested, or convicted) portrayed on television news who were associated with crimes tracked by the California Department of Justice (1996, 1997). We computed chi-square statistics to determine whether these percentages were significantly different. An alpha level of .05 was used for all statistical tests. As Table 4 shows, 37\% of all perpetrators portrayed on television news were Black, 29\% were Latino, 21\% were White, and 13\% were other (e.g., Native Americans, Asians), $\chi^{2}(3, N=126)=41.17, p<.001$. This trend is continued for felonies. As shown in Table 5, 44\% of all felony perpetrators portrayed on television news were Black, 34\% were Latino, 18\% were White, and $4 \%$ were other, $\chi^{2}(3, N=106)$ $=36.64, p<.001$. 


\begin{tabular}{|c|c|c|c|c|}
\hline Race & $\begin{array}{l}\text { Arrest } \\
\text { rate }^{a} \\
\%\end{array}$ & $\begin{array}{l}\text { TV } \\
\text { perp. } \\
\%\end{array}$ & $\begin{array}{l}\% \text { point } \\
\text { differential }^{c}\end{array}$ & $\begin{array}{c}95 \% \text { confidence } \\
\text { interval } \\
\%\end{array}$ \\
\hline Black & 21 & 37 & $+16^{*}$ & $+/-7$ \\
\hline White & 28 & 21 & $-07^{*}$ & $+1-6$ \\
\hline Latino & 47 & 29 & $-18^{*}$ & $+1-6$ \\
\hline Other & 4 & 13 & $+9^{*}$ & $+/-5$ \\
\hline
\end{tabular}

$\chi^{2}(3, N=126)=41.17, p<.001$.

a Percentage of Blacks, Whites, Latinos, and others who were arrested, according to the California Department of Justice Criminal Profile for 1995 and 1996.

b Percentage of Blacks, Whites, Latinos, and others who appeared as perpetrators on local television news.

c Difference between the television percentage and the arrest rate percentage for each racial group (TV \% - Arrest \%).

* Percentage point differential outside the confidence interval.

In step two, we subtracted these television news proportions of perpetrators from the proportion of perpetrators arrested, according to the California Criminal Justice Profile for 1995 and 1996 for Los Angeles and Orange counties (1996, 1997). The resulting difference is represented in Table 4 and Table 5 as the percentage point differential. This gives us some indication of the size and direction of differences between television news and arrest reports. In the final step, we calculated a sampling error because these proportions are estimates of population parameters from a sample of news programs. Therefore, we calculated a 95\% confidence interval around each sample estimate of the proportion of perpetrators on television news (Moore \& McCabe, 1989). This confidence interval is represented in the last column of Table 4 and Table 5 . If the percentage point differential exceeded the $95 \%$ confidence interval, we considered the corresponding television proportion a statistically significant underrepresentation or overrepresentation.

Potential problems with the interreality comparison. The interreality comparison as described above is somewhat imprecise for two reasons. First, all perpetrators, whether sought or arrested on television news, are compared to arrest rates. Second, repeat perpetrators are included in the analysis. The point of the interreality comparison is to compare television portrayals to some other indicator of social reality in order to create a precise index of overrepresentation or underrepresentation. However, television news portrays perpetrators at all stages of the judicial process, including when they are sought, arrested, or convicted, and they may repeat the story several times. There may be a difference between which racial groups are sought for crimes and which groups are arrested. In addition, high 


\begin{tabular}{|c|c|c|c|c|}
\hline Race & $\begin{array}{l}\text { Arrest } \\
\text { rate }^{a} \\
\%\end{array}$ & $\begin{array}{l}\text { TV } \\
\text { perp. } \\
\%\end{array}$ & $\begin{array}{c}\% \text { point } \\
\text { differential }^{c}\end{array}$ & $\begin{array}{c}95 \% \text { confidence } \\
\text { interval } \\
\%\end{array}$ \\
\hline Black & 25 & 44 & $+19^{*}$ & $+/-8$ \\
\hline White & 23 & 18 & -5 & $+1-6$ \\
\hline Latino & 47 & 34 & $-13^{*}$ & $+/-7$ \\
\hline Other & 5 & 4 & -1 & $+1-3$ \\
\hline
\end{tabular}

$\chi^{2}(3, N=106)=36.64, p<.001$.

a Percentage of Blacks, Whites, Latinos, and others who were arrested felons, according to the California Department of Justice Criminal Profile for 1995 and 1996.

b Percentage of Blacks, Whites, Latinos, and others who appeared as felony perpetrators on local television news.

c Difference between the television percentage and the arrest rate percentage for each racial group (TV \% - Arrest \%).

* Percentage point differential outside the confidence interval.

profile cases may spur multiple newscasts about the perpetrators involved in the crime. If there is some correlation between race and high profile cases, certain racial groups may be more likely to be repeated than others. This becomes problematic when comparing these television news depictions to crime reports because arrest rates include only those in custody, and each defendant is only counted once.

Both of the issues outlined above are only seriously problematic if some racial groups are more likely than others to be portrayed as sought perpetrators or if some racial groups are more likely than others to be repeated across newscasts. In order to ensure this was not the case, we conducted two chi-square analyses. A chi-square analysis revealed that the inclusion of sought perpetrators was not problematic because all of the racial groups had approximately equal numbers of sought perpetrators portrayed on television news, $\chi^{2}(3, N=544)=2.63, p<.452$. The inclusion of repeated perpetrators in the analysis was not problematic because all of the racial groups had approximately equal numbers of repeated perpetrators on television news, $\chi^{2}(3, N=213)=1.32, p<.723$.

Results of the interreality comparison of perpetrators. As Table 4 shows, Blacks were more likely to be portrayed as perpetrators of crime on television news (37\%) than to be arrested, according to crime reports (21\%). Given the confidence interval of plus or minus 7 percentage points, this is a statistically significant 16 percentage point difference. Based on this interval, the difference between the proportion of Black perpetrators portrayed on television news and those arrested according to crime reports may be as low as 11 percentage points or as high as 25 percentage points. 


\begin{tabular}{|c|c|c|c|c|}
\hline Race & $\begin{array}{c}\text { Employment } \\
\text { record }^{a} \\
\%\end{array}$ & $\begin{array}{l}\text { TV } \\
\text { off. }^{\text {b }} \\
\%\end{array}$ & $\begin{array}{c}\% \text { point } \\
\text { differential }\end{array}$ & $\begin{array}{c}95 \% \text { confidence } \\
\text { interval } \\
\%\end{array}$ \\
\hline Black & 11 & 14 & +3 & $+1-6$ \\
\hline White & 59 & 69 & $+10^{*}$ & $+1-7$ \\
\hline Latino & 25 & 10 & $-15^{*}$ & $+1-6$ \\
\hline Other & 5 & 7 & +3 & $+/-5$ \\
\hline
\end{tabular}

$\chi^{2}(3, N=119)=147.05, p<.001$.

a Percentage of Blacks, Whites, Latinos, and others who were employed as officers, according to the Los Angeles County Departmental Personnel Strength (1996); County of Orange Equal Employment Opportunity Access Office (1996) and Los Angeles Police Department Attorney Media Relations (1996).

b Percentage of Blacks, Whites, Latinos, and others who appeared as officers on local television news.

c Difference between the television percentage and the employment record percentage for each racial group (TV \% - Employment \%).

* Percentage point differential outside the confidence interval.

This difference was even larger for felonies. Blacks were more likely to be portrayed as felons on television news (44\%) than to be arrested for felonies (25\%). Given the confidence interval of 8 percentage points for the television proportion, this difference is also statistically significant.

Tables 4 and 5 also display the percentage of Latino perpetrators portrayed on television news compared to the proportion of Latino perpetrators who were arrested. Latinos were less likely to be portrayed as perpetrators of crime on television news (29\%) than to be arrested (47\%), according to crime reports. Given the $6 \%$ confidence interval, this difference is statistically significant. As displayed in Table 5, this trend continued for felonies. Latinos were significantly less likely to be portrayed as felons on television news (34\%) than to be arrested for felonies according to crime reports (47\%).

Whites were less likely to be portrayed as perpetrators of crime on television news than to be arrested according to crime reports. Whites were $21 \%$ of the perpetrators on television news, but $28 \%$ of those arrested according to crime reports. Given the $6 \%$ confidence interval on either side of the estimate, this difference is statistically significant. However, there was not a statistically significant difference between White felons shown on television news (18\%) and White felons who were arrested (23\%).

Others (e.g., Asians) were significantly more likely to be portrayed as perpetrators on television news (13\%) than to be arrested, according to crime reports (4\%). 
However, there were no statistically significant differences between others portrayed as felons on television news (4\%) and others arrested for felonies (5\%).

Interreality Comparison of Law Defenders on Television News to Employment Records The second part of our third hypothesis predicted that the distribution of law defender roles on television news would be inconsistent with those in employment records. This hypothesis was also supported. As shown in Table 6, 69\% of all police officers were White, 14\% were Black, 10\% were Latino, and 7\% were other, $\chi^{2}(3, N=119)=147.05, p<.001$. We subtracted these television proportions from the proportions reported in employment records provided by the County of Orange (1996), Los Angeles County Sheriff's Department (1996), and the Los Angeles Police Department (1997) and calculated a 95\% confidence interval for each proportion.

Whites were more likely to be portrayed as police officers on television (69\%) than to be employed as officers in Los Angeles and Orange counties (59\%). Given the confidence interval of $8 \%$ on either side of the estimate of White television officers on the news, this is a statistically significant 10 percentage point difference. Based on this interval, the difference between the proportion of White officers portrayed on television news and those employed, according to government records, may be as low as 2 or as high as 18 percentage points.

Conversely, Latinos were less likely to be portrayed as officers on television news (10\%) than to be employed as officers in Los Angeles and Orange counties (25\%). Given the confidence interval of $6 \%$, this represents a statistically significant difference.

There were no statistically significant differences for Blacks or others on these programs. Blacks comprised 14\% of the officers portrayed on television news and $11 \%$ of those employed as officers according to county records. Others were $7 \%$ of the officers portrayed on television and $5 \%$ of those employed, according to county records.

\section{Discussion}

\section{Review of Findings}

Three indexes were used in this study to produce a more comprehensive assessment of the portrayal of Blacks, Latinos, and Whites as lawbreakers and law defenders on television news. First, intergroup comparisons revealed that Blacks and Latinos were more likely than Whites to be portrayed as perpetrators of crime on television news. Second, interrole comparisons revealed that Blacks and Latinos were more likely to be portrayed as perpetrators than as police officers on television news. Whites, however, were less likely to be portrayed as perpetrators than as officers. Third, interreality comparisons revealed that Blacks were overrepresented, Latinos were underrepresented, and Whites were somewhat underrepresented as perpetrators on television news. However, Blacks were neither overnor underrepresented, Latinos were underrepresented, and Whites were overrepresented as police officers on television news.

Below we discuss some of the limitations of this research. Afterward, we describe two phenomena that may explain the misrepresentations uncovered in this study. 
Limitations of the Present Study

Only Los Angeles-based stations were included in the sample because they were drawn from the larger NTVS sample, which taped all of its programs in the Los Angeles market. These findings thus cannot be readily generalized to other areas around the country. However, when these findings are compared to the content analyses of Romer et al. (1998), who conducted their analysis in Philadelphia, and Entman (1992), who conducted his analysis in Chicago, the characteristics of the Los Angeles market appear to be similar to other large urban areas in the U.S.

Further, in this study, we examined the portrayals of Blacks and Latinos separately to allow for a more sophisticated analysis. The findings revealed that Blacks receive negative media attention, whereas Latinos do not receive much attention at all. However, one limitation of this study is that we did not include Spanishspeaking stations in the sample of programs analyzed. It is possible that the portrayal of Latino lawbreakers on these stations differs from the portrayals featured on mainstream broadcasts. However, many of these Spanish-speaking stations, including Telemundo, often use the same news feeds as mainstream stations. Therefore, the impact of Spanish-speaking stations on underrepresentation of Latinos as perpetrators of crime and law defenders needs to be investigated more thoroughly in the future.

\section{What Causes Overrepresentation and Underrepresentation?}

The overrepresentation of Blacks as perpetrators, the underrepresentation of Latinos as perpetrators and as police officers, and the overrepresentation of Whites as police officers can be explained by two complementary theoretical perspectives. One perspective maintains that the portrayals uncovered in the present study are the result of an ethnic blame discourse such that African Americans and Latinos are portrayed in roles in which they cause harm to Whites (Romer et al., 1998). The other suggests that these depictions are an outgrowth of the structural limitations of television news reporting. Both of these perspectives are explored below.

It could be argued that the overrepresentation of Black lawbreaking and White law defending on television news is part of an ethnic blame discourse being carried out in the media (Romer et al., 1998). This discourse is ethnocentric talk that becomes routinized in everyday speaking and shapes the thoughts and actions of persons exposed to the discourse. The ethnic blame discourse frames problem behavior committed by ethnic Others (e.g., Blacks and Latinos) as intergroup conflict and accentuates the harmful effects of the behavior on the in-group (e.g., Whites). Those who espouse this perspective claim that such a discourse is pervasive, that it occurs in interpersonal and mass media contexts, and that it affects both out-group and dominant members (Romer et al., 1998; van Dijk, 1993).

We believe that an ethnic discourse does operate, but that it is an outgrowth of the stereotyping process. According to the social cognition literature, mere exposure to African Americans or Latinos or to stereotypic attributes regarding these groups (e.g., criminal) can unconsciously and automatically activate stereotypic associations (Devine, 1989). Both in-group members and out-group members may process information in this way (Steele \& Aronson, 1995). News editors and re- 
porters are not exempt from this phenomena. As a result, they may make decisions about the newsworthiness of events based on a discourse rooted in unconscious stereotypical assumptions. Under such circumstances, Black perpetration of crime, particularly if Whites are victims, may be deemed highly newsworthy by news gatherers who may unconsciously conform to these ethnocentric discursive practices.

Although an ethnic blame discourse is an intriguing explanation for the overrepresentation of Black lawbreaking found in the current investigation, it does not fully explain all of the findings in this study. Specifically, the ethnic blame discourse does not adequately explain the underrepresentation of Latinos as both perpetrators and officers uncovered in the present research. An ethnic blame discourse predicts that Latinos would have been overrepresented as perpetrators, not underrepresented. For this reason, an ethnic blame discourse is an insufficient explanation by itself for the findings in this study.

However, a complementary perspective may be found in the structural constraints put on news gatherers. Although an ethnic blame discourse based on stereotypes about out-groups may affect what is aired on television news, structural limitations or institutional biases may also shape mass media depictions of race and crime. The structural limitations perspective essentially posits that the news-gathering process has an effect on the way that messages are framed (Graber, 1980; Iyengar \& Kinder, 1987). It is possible that both of these forces work together to produce the portrayals uncovered in this study. Below we explain how each of these perspectives potentially contributes to the major findings in this study.

Blue-collar crime and Black overrepresentation. The vast majority of crimes reported on television news may be considered "blue-collar crimes." According to Delgado (1994), blue-collar crimes are those offenses closely monitored by official government agencies that involve some level of face-to-face interpersonal force. Examples of blue-collar crime include murder and robbery. Blue-collar crimes can be distinguished from "white-collar crimes," which are typically nonviolent, economic crimes that include some degree of fraud, collusion, or deception and lack face-to-face interpersonal force. Examples of white-collar crimes include bribery, embezzlement, defense procurement fraud, consumer fraud, price-fixing, insider trading, and savings-and-loan scandals.

An ethnic blame discourse perspective would claim that television news' focus on blue-collar crime is a result of a manipulation by "elites" to elevate the problem of blue-collar crime committed by Blacks over that of white-collar crime committed by Whites (Delgado, 1994). However, there are also three structural limitations of the news media that may also contribute to an emphasis on blue-collar crime over white-collar crime. First, the level of face-to-face interpersonal force featured in blue-collar crime may be more attractive to news gatherers because of the easy identification of victims to whom the audience can relate (Dorfman, Woodruff, Chavez, \& Wallack, 1997). Second, news agencies typically rely on official sources, who may be more likely to devote attention to blue-collar rather than whitecollar crime (Graber, 1980; Kanis, 1991; Pritchard \& Hughes, 1997). Third, the format of television news encourages an emphasis on the visual and the dramatic (Kanis, 1991). 
This emphasis on blue-collar crime is more likely to draw attention to Black crime in the minds of viewers because Blacks are much more likely to be bluecollar criminals than white-collar criminals. Committing a white-collar crime requires a certain amount of economic power and influence. Given that Blacks often do not have the economic resources that Whites do, they are more likely to be blue-collar than white-collar criminals (Gordon, 1998; Poveda, 1994). Whitecollar crime is typically committed by White, male, wealthy, and politically powerful offenders. An increase in white-collar reporting would likely lead to an increase in the number of White perpetrators, which would result in a distribution of perpetrators that is less likely to emphasize Black criminality. The focus on blue-collar criminality probably deflates the number of White perpetrators while inflating the number of Black perpetrators on television news.

Language barriers and Latino underrepresentation. It is harder to find an ethnic blame discourse explanation for Latino underrepresentation, but perhaps the lack of focus on Latino perpetration results from Latinos being framed as a problem people in other areas besides crime (e.g., immigration). It is more plausible that the structural limitations of the news media have a more profound influence than ethnic blame in producing the Latino underrepresentation found in this study. These limitations may contribute to the absence of Latinos on television news by discouraging journalists from overcoming the boundaries (e.g., language and culture) to the Latino community. For instance, Fitzgerald (1994) reported that Latinos were underrepresented as news reporters. Latino reporters fluent in Spanish may be able to traverse the barriers that limit the access of English-speaking news agencies to Latinos. As U.S. population demographics continue to change, there is evidence that news agencies may begin to work harder at courting the Latino majority (Stanley, 1996). As this occurs, it is possible that Latino underrepresentation will begin to disappear.

Structural limitations and the overrepresentation of White officers. An ethnic blame discourse perspective posits that Whites would be portrayed as officers because they are part of the dominant group and as such are ascribed roles as protectors and victims. However, structural limitations might also contribute to the overrepresentation of Whites as police officers. Higher ranking police officers and detectives are more likely to receive airtime than rank-and-file officers. Whites may be more likely to be higher ranking officers (County of Orange, 1996; Los Angeles County Sheriff's Department, 1996; Los Angeles Police Department, 1997). There may be an underrepresentation of Black and Latino detectives on the police force that results in White officers receiving more attention from news agencies than Black and Latino officers. The comparison data used in this analysis indicate that Blacks and Latinos compose less than $2 \%$ of all officers above the level of sergeant. It is possible that news agencies, in their quest for official sources, typically rely on information from high ranking officers who may be more likely to be White than Latino or Black.

In summary, an ethnic blame discourse suggests that Black crime is overrepresented because ethnic out-groups are blamed for the problems of Whites. Whites, on the other hand, occupy roles as officers who fight this problem. Although an intriguing idea, an ethnic blame discourse perspective does not offer a sufficient 
explanation for the underrepresentation of Latinos found in the present study. A complementary explanation may be found in the structural limitations of news media. The structural limitations perspective claims that language barriers contribute to Latino underrepresentation, that a focus on blue-collar crime contributes to Black overrepresentation as criminals, and that demographics and a reliance on official sources contribute to White overrepresentation as officers. Further research is necessary to determine how much each of these phenomena contributes to the depictions uncovered in the current study.

\section{Summary and Conclusions}

We utilized intergroup, interrole, and interreality comparisons to investigate whether African Americans, Latinos, and Whites are portrayed as lawbreakers or law defenders. The intergroup comparisons revealed that Blacks and Latinos were more likely than Whites to appear as perpetrators. The interrole comparisons revealed that Blacks and Latinos are more likely to appear as perpetrators than as officers whereas the opposite is true for Whites. Most importantly, these intergroup and interrole comparisons were anchored by interreality comparisons. These interreality comparisons revealed that African Americans were overrepresented as perpetrators, and Latinos and Whites were underrepresented as perpetrators. Furthermore, Blacks were neither over- nor underrepresented as officers, but Latinos were underrepresented and Whites were overrepresented in this law defender role.

This study extends what we know about the portrayal of race and crime on local television news in two important ways. First, it provides additional support for the conclusions reached by prior studies on the portrayal of African Americans on television news (Entman, 1992, 1994). Based on each of the indicators in the present study, Blacks are clearly overrepresented as lawbreakers on news programs. Second, this study provides one of the first comprehensive assessments of Latinos on television news. Although much of the prior literature suggests that Latinos will be portrayed in a similar fashion to African Americans, clearly our results suggest this is not the case. Although intergroup and interrole comparisons seem to indicate that Latinos are linked with criminal behavior, Latinos are actually underrepresented as both officers and perpetrators, according to our interreality comparisons.

Much more research is needed to understand the implications of these portrayals on intergroup relations. We suggest that the immediate work must be undertaken with regard to how these portrayals might encourage or discourage stereotyping and increase fear of African Americans. Cultivation theory as well as the mechanisms explicated in the social cognition literature suggest that these representations may have a powerful impact on viewers. Other future work might seek to replicate our results with regard to Latinos and investigate the effects of Latino portrayals on viewers.

\section{References}

Armstrong, B., \& Neuendorf, C. (1992). TV entertainment, news, and racial perceptions of college students. Journal of Communication, 42(3), 153-176. 
Barlow, M. H., Barlow, D. E., \& Chiricos, T. G. (1995). Economic conditions and ideologies of crime in the media: A content analysis of crime news. Crime \& Delinquency, 41(1), 3-19.

Bogatz, G. A., \& Ball, S. (1972). The second year of Sesame Street: A continuing evaluation. Princeton, NJ: Educational Testing Service.

California Department of Justice. (1996). Criminal justice profile, 1995: Los Angeles \& Orange County. Sacramento, CA: Division of Law Enforcement, Bureau of Criminal Information and Analysis, Law Enforcement Information Center.

California Department of Justice. (1997). Criminal justice profile, 1996: Los Angeles \& Orange County. Sacramento, CA: Division of Law Enforcement, Bureau of Criminal Information and Analysis, Law Enforcement Information Center.

Clark, C. (1973). The concept of legitimacy in Black psychology. In E. G. Epps (Ed.), Race relations: Current perspectives (pp. 332-354). Cambridge, MA: Winthrop.

Cohen, J. (1960). A coefficient of agreement for nominal scales. Educational and Psychological Measurement, 20, 37-46.

County of Orange. (1996). County of Orange statistical picture (Comp. Codes 060, 062, 109, 143, 026, 116, 122). Orange, CA: County of Orange Equal Employment Opportunity Access Office.

Delgado, R. (1994). Rodrigo's eight chronicle: Black crime, White fears—on the social construction of threat. Virginia Law Review, 80, 503-548.

Devine, P. G. (1989). Stereotypes and prejudice: Their automatic and controlled components. Journal of Personality and Social Psychology, 56, 5-18.

Deroche, C., \& Deroche, J. (1991). Black and White: Racial construction in television police dramas. Canadian Ethnic Studies, 23(3), 69-91.

Dominick, J. R. (1978). Crime and law enforcement in the mass media. In C. Winick (Ed.), Deviance and mass media (pp. 105-128). Beverly Hills, CA: Sage.

Dorfman, L., Woodruff, K., Chavez, V., \& Wallack, L. (1997). Youth and violence on local television news in California. American Journal of Public Health, 87, 1311-1316.

Entman, R. (1992). Blacks in the news: Television, modern racism, and cultural change. Journalism Quarterly, 69, 341-361.

Entman, R. (1994). Representation and reality in the portrayal of Blacks on network television news. Journalism Quarterly, 71, 509-520.

Fitzgerald, M. (1994). State of Hispanic America. Editor E Publisher, 127(32), 11.

Gans, H. J. (1979). Deciding what's news: A study ofCBS Evening News, NBC Nightly News, Newsweek, and Time. New York: Pantheon Books.

Gerbner, G. (1969). Toward "cultural indicators": The analysis of mass mediated public message systems. AV Communication Review, 17(2), 137-148.

Gerbner, G. (1990). Epilogue: Advancing the path of righteousness (maybe). In N. Signorielli \& M. Morgan (Eds.), Cultivation analysis: New directions in media effects research (pp. 242-262). Newbury Park, CA: Sage.

Gerbner, G., Gross, L., Morgan, M., \& Signorielli, N. (1980). The "mainstreaming" of America: Violence profile no. 11. Journal of Communication, 30(3), 10-29.

Gilliam, F. D., Iyengar, S., Simon, A., \& Wright, O. (1996). Crime in Black and White: The violent, scary world of local news. Harvard International Journal of Press/Politics, 1, 623. 
Gordon, Randall A. (1988). Perceptions of blue-collar and white-collar crime: The effect of defendant race on simulated juror decisions. Journal of Social Psychology, 128(2), 191-197.

Gorn, G. I., Goldberg, M. E., \& Kanungo, R. N. (1976). The role of educational television in changing intergroup attitudes of children. Child Development, 47, 277-280.

Graber, D. A. (1980). Crime news and the public. New York: Praeger.

Hall, S., Critcher, C., Jefferson, T., Clarke, J., \& Roberts, B. (1978). Policing the crisis: Mugging, the state, and law and order. New York: Holmes \& Meier.

Hamilton, D. L., Stroessner, S. J., \& Driscoll, D. M. (1994). Social cognition and the study of stereotyping. In P. G. Devine, D. L. Hamilton, \& T. M. Ostrom (Eds.), Social cognition: Impact on social psychology (pp. 292-323). San Diego, CA: Academic Press.

Imrich, D. J., Mullin, C., \& Linz, D. (1995). Measuring the extent of prejudicial pretrial publicity in major American newspapers: A content analysis. Journal of Communication, 45(3), 94-117.

Iyengar, S., \& Kinder, D. (1987). News that matters. Chicago: University of Chicago Press.

Jerin, R. A., \& Fields, C. B. (1994). Murder and mayhem in USA Today: A quantitative analysis of the national reporting of states' news. In G. Barak (Ed.), Media, process, and the social construction of crime: Studies in newsmaking criminology (pp. 187-202). New York: Garland.

Johnson, J. D., Adams, M. S., Hall, W., \& Ashburn, L. (1997). Race, media and violence: Differential racial effects of exposure to violent news stories. Basic and Applied Social Psychology, 19(1), 81-90.

Jones, J. M. (1986). Racism: A cultural analysis of the problem. In J. Dovidio \& S. Gaertner (Eds.), Prejudice, discrimination, and racism (pp. 279-314). Orlando, FL: Academic Press.

Kaniss, P. (1991). Making local news. Chicago: University of Chicago Press.

Klite, P. K., Bardwell, R. A., \& Salzman, J. (1997). Local TV news: Getting away with murder. Harvard International Journal of Press/Politics, 2, 102-112.

Krippendorff, K. (1980). Content analysis: An introduction to its methodology. Newbury Park, CA: Sage.

Kunkel, D., Wilson, B. J., Linz, D., Potter, J., Donnerstein, E., Smith, S. L., Blumenthal, E., \& Gray, T. (1996). Violence in television programming overall: University of California study. In Mediascope (Ed.), National television violence study: Scientific papers 1994-1995 (pp. I-1-I-171). Studio City, CA: Mediascope.

Los Angeles County Sheriff's Department. (1996). Departmental personnel strength: LA County Sheriff year in review 1996. Monterey Park, CA: Los Angeles Sheriff's Department Management Information Services.

Los Angeles Police Department. (1997). Sworn personnel by rank, gender, E ethnicity (Report PR 91 and HLRPT 17). Los Angeles, CA: Los Angeles Police Department Information Resources Division.

Miller, M. C. (1998). It's a crime: The economic impact of the local TV news in Baltimore (Technical Report). New York: New York University Project on Media Ownership.

Moore, D. S., \& McCabe, G. P. (1989). Introduction to the practice of statistics. New York: W. H. Freeman.

Nielsen Media Research. (1994). Nielsen station index: Los Angeles market service. Los Angeles, CA: Author.

Oliver, M. B. (1994). Portrayals of crime, race, and aggression in "reality-based" police shows: A content analysis. Journal of Broadcasting E Electronic Media, 38, 179-192. 
Perreault, W. D., \& Leigh, L. E. (1989). Reliability of nominal data based on qualitative judgments. Journal of Marketing Research, 26, 135-148.

Perse, E. M. (1990). Cultivation and involvement with local television news. In N. Signorielli \& M. Morgan (Eds.), Cultivation analysis: New directions in media effects research (pp. 51-69). Newbury Park, CA: Sage.

Potter, J., Linz, D., Wilson, B., Donnerstein, E., Kunkel, D., Smith, S., Blumenthal, E., \& Grey, T. (1998). Content analysis of entertainment television: New methodological developments. In J. Hamilton (Ed.), Television Violence and Public Policy (pp. 55-104). Ann Arbor: University of Michigan Press.

Poveda, T. G. (1994). Rethinking white-collar crime. Westport, CT: Praeger.

Pritchard, D. P., \& Hughes, K. D. (1997). Patterns of deviance in crime news. Journal of Communication, 47(3), 49-67.

Romer, D., Jamieson, K. H., \& De Coteau, N. J. (1998). The treatment of persons of color in local television news: Ethnic blame discourse or realistic group conflict. Communication Research, 25, 268-305.

Sorenson, S. B., Manz, J. P., \& Berk, R. A. (1998). News media coverage and the epidemiology of homicide. American Journal of Public Health, 88, 1510-1514. Retrieved July 19, 1999: from the Web: http://medsearch.lib.umich.edu/ovidweb/ovidweb.cgi? T=fullText\&RS= Results $\% 2$ etitle $\% 7 \mathrm{c} 0 \% 7 \mathrm{cFull}+$ Text $\& \mathrm{D}=\mathrm{ftall} \& \mathrm{~S}=\mathrm{CHMCAFDPCGLNBP}$

Stanley, T. L. (1996). New network sees potential in the city: Urban Television Network forms division to produce news programming targeting Blacks, Latinos and Asians. MediaWeek, 6, 23.

Steele, C. M., \& Aronson, J. (1995). Stereotype threat and the intellectual test performance of African Americans. Journal of Personality and Social Psychology, 69, 797-811.

Turk, J. V., Richstad, J., Bryson, R. L., \& Johnson, S. M. (1989). Hispanic Americans in the news in two southwestern cities. Journalism Quarterly, 66, 107-113.

Van Dijk, T. A. (1993). Elite discourse and racism. Newbury Park, CA: Sage.

Wilson, B. J., Kunkel, D., Linz, D., Potter, J., Donnerstein, E., Smith, S. L., Blumenthal, E., \& Berry, M. (1998). Violence in television overall: University of California study. In National Television Violence Study (Ed.), National Television Violence Study 2, (pp. 3-204). Thousand Oaks, CA: Sage. 